\title{
Writing Self, Writing Empire: Chandar Bhan Brahman and the Cultural World of the Indo-Persian State Secretary
}

\author{
Rajeev Kinra
}

Oakland: University of California Press, 2015. 371 pages.

The seventeenth century marks an exciting period in the life of Persian literary cultures in northern India. Established as a language of administration by Turco-Afghans in the early thirteenth century, several centuries later Persian had extended well beyond its initial administrative strongholds to become an important medium for literary and religious composition, historiography, and translation. In a literary environment that prized both literary aesthetics and fierce rivalries, the massive textual production on vastly diverse subjects, as well as the presence of literary salons, standalone bookstalls, and mush a 'irahs (poetic assemblies), cumulatively point to a lively Persian literary culture that echoed across political, religious, and socio-cultural terrains.

Unfortunately, most of the scholarship on Persian in the medieval Indian context over the past decades has failed to illuminate this dynamic scene. Moreover, most studies seek to highlight Persian's influence on India or examine India's civilizational impact on Persian. Both paradigms assume a natural (read: Iranian) ecumene for Persian and thus do not critically consider the slippage between linguistic, ethnic, and geographic designations when 
defining Persian's place in India. A powerful example of this slippage is seen in the category of sabk-i Hindi (Indian-style Persian poetry), a maligned literary category developed by the Iranian scholar Mohammad-Taqi Bahar (d. 1951) that maps a transnational Persian literary culture onto the level of geography and ethnicity (India). Kinra's Writing Self, Writing Empire seeks to re-theorize more precisely the role of Persian in the Mughal social space by focusing on the life, career, and literary productivity of Chandar Bhan Brahman, one of the most distinguished litterateurs and munshis (state secretaries) of the Indo-Persianate world.

Spanning the rule of four emperors, Chandar Bhan's career begins with Akbar (r. 1556-1605), considered the greatest Mughal emperor, and ends with Aurangzeb (r. 1658-1707), who is often held responsible for the dynasty's decline. Throughout his career, Chandar Bhan formed relationships with Mughal officials and other munshis. His monograph on secretarial conduct, Munsha'ät-i Brahman (Brahman's Compositions), was emulated by his contemporaries and celebrated well after his death in the 1660s. Whereas his epistolary writings offer insights into the administrative practices of the court, his autobiographical writings can be read as an early modern example of selffashioning. Attesting to this scholar's wide-ranging works, he also composed and recited poetry on formal and informal occasions.

In the book's introduction, Kinra raises an important point: Despite Chandar Bhan's status as an upper-caste Hindu (hence his penname "Brahman"), he saw no tension between his religious identity and his deep investment in Persian. After all, he lived in a world in which language was not an automatic signifier for ethnic or religious identities.

Chapter 1 investigates Chandar Bhan's lineage, social networks, and intellectual milieu. Kinra challenges the common misconception that the postAkbar Mughal period was an era of declining tolerance and civility that paved the way for a "return to orthodoxy" (p. 20). If this were the case, Kinra asks, why was this alleged move toward uncompromising orthodoxy not documented by such a prominent Hindu munshi? Chandar Bhan's experiences, as reflected in his own writings, reaffirm Kinra's reinterpretation of the seventeenth century as one that built on Akbar's institutional reforms. For instance, the munshi's mentors Afzal Khan (d. 1639) and Sa'd Allah Khan (d. 1656) neither took issue with his Brahman heritage nor tried to convert him. In short, one's ethnic or religious affiliation did not necessarily predetermine one's involvement in political enterprises or literary endeavors.

Chapter 2 turns to Chandar Bhan's Chahār Chaman (Four Gardens) and Munsha'ät-i Brahman to address the question of "What makes a mun- 
shi?" Ishtiyaq Ahmad Zilli (2000), Muzaffar Alam and Sanjay Subrahmanyam (2004), and other scholars have already taken up this topic. Modern scholars have questioned Chahär Chaman's historical value due to its thematic discontinuity. Kinra, however, finds new ways to work with the text by following its own organizational logic. The value of this approach can be seen in the fact that each chaman elucidates shared values of Indo-Persian munshis. Inheritors of a centuries-old tradition, a Mughal munshi would be well versed in "canonical treatises on statecraft, civility and ethics" and "mystical civility" (p. 61). Any munshi would be expected to gain proficiency in the craft of insha', khwushnivisi (penmanship), and poetic composition. The realms of the secretarial art (munshigiri) and statesmanship were interconnected in Mughal India. Munshis and wazirs alike aimed to develop the aforementioned profiles because they could not rely on "high birth and martial valor" (p. 65).

Chapter 3 considers Chandar Bhan's views on Muslim rule in India in general and Shah Jahan's (r. 1628-58) court in particular. His Tārīkh-i Rajahā-yi Dihlī (History of the Kings of Delhi) embeds the Mughal emperors in the political imagination of their elite Indian audience by placing them within a genealogy of just and legitimate Hindustani rulers beginning with King Yuddhishtira from the Sanskrit epic Mahābhārata and ending with Shah Jahan.

Kinra's analysis complements existing studies on the Mughal concept of kingship, particularly Audrey Truschke's Culture of Encounters (2016), which examines the process of collaboration among Persian-language translators, Sanskrit literati, and Hindavi-speaking intermediaries in rewriting the Mahābhārata into Razmnamah (Battle-poem), an Indo-Persian epic of importance to the Mughal imperium. His descriptions of Shah Jahan's personality and daily routine, secretarial arts, and "the hustle and bustle of life" in different provinces of the empire highlight India's ethnic and geographic diversity, thereby capturing the period's sense of epochal change.

Chapter 4 examines the third and fourth chamans, which comprise Chandar Bhan's brief autobiography, personal letters, and philosophical meditations. Kinra places his subject's personal "I" within the larger context of self-fashioning, a vital aspect of the early-modern self that is largely assumed to have taken shape exclusively in seventeenth-century Europe. Many scholars have previously studied letters as evidence for sociological or historical research. The value of Kinra's intervention, however, lies in considering the poetics of Mughal letter writing: the inclusion of poetic tropes, mystical sensibilities, and freshly composed ghazals. Letters are not just literary docu- 
ments, for their "meta-awareness of [being] letters themselves" renders them "important cultural artifacts" to be collected and preserved (p. 180). Chahār Chaman's final pages contain metaphysical observations (nuktas [points]), which were included in the author's correspondence with his brothers and thus can be seen as an "informal vehicle for the circulation of esoteric ideas" (p. 199). Previously relegated to an afterthought, Kinra brings nuktas back to a critical discussion of Chandar Bhan's intellectual milieu.

Chapter 5 examines the poetry of Chandar Bhan and the global contexts of $t \bar{a} z a-g \bar{u} ' \bar{l}$ (fresh speak), a category to which many seventeenth-century poets and literati ascribed, versus the modern sabk-i Hindi. It is worth noting that the racial connotations of hindi in nineteenth-century Iran are not dissimilar to the term negro and its contemptuous variants. Kinra, on the other hand, relates the proliferation of $t \bar{a} z a-g \bar{u} ' \bar{l}$ to a transregional sense of newness. By the end of Akbar's reign, a sense of "epochal change" echoed well beyond Mughal India (p. 202).

The arrival of the Islamic calendar's new millennium (1591-92) was just one part of a multifaceted concept of millenarianism that took form in the post-Timurid period. Literary works of this period embody this newness. The tāza terminology, preferred by Kinra, was first used in Abu al-Fath Gilani's circle, which included such poets as Shaikh Faizi (d. 1595) and 'Urfi Shirazi (d. 1591). The author considers the formal innovations of tāza-g ' ' $\bar{\imath}$ as a "dynamic response to the anxieties and exuberance of global early modernity" (p. 237). Although scholars like Subrahmanyam and Azfar Moin have already noted millenarianism's role in the formation of sacred, Kinra is the one who has started a conversation regarding its literary implications.

Chapter 6 studies the cultural memory of Chandar Bhan during the Mughal dynasty's decline. Within a few decades after his passing (ca. 1662-64), his career became the subject of lively anecdotes and legends. Kinra, however, shows how each generation of tazkirah (commemorative compendia) writers in fact reinvented this figure in light of their own political identity. For the late seventeenth-century literary critic Mohammad Afzal Sarkhwush, for example, Chandar Bhan's literary identity is increasingly also about his Hindu-ness. And so Sarkhwush reproduces a bayt (line) that he claims was so heretical that it almost got him executed by Emperor Shah Jahan (p. 259). There is no evidence of this event though, according to Kinra. Others repeat it all the same.

In twentieth-century commentaries, the memory of "the irreverent Hindu" has become connected to "tales of heroic 'Hindu' resistance to 'Muslim' rule." Furthermore, Chandar Bhan's investment in Persian is seen as a symbol of "Muslim supremacy" forcing a Hindu to compose in a "foreign" language. 
What emerges through this "sequence of articulations" is not the legacy of Chandar Bhan, but rather the identity politics of twentieth-century South Asia (p. 285). Kinra's critical approach toward such oft-cited anecdotes, like those employed by Paul E. Losensky in Welcoming Fighani (1998), should be seen as a model of literary criticism in a tradition replete with anecdotes about poets and patrons.

Kinra returns Chandar Bhan to his cultural milieu, wherein the role of the poet, munshi, and patron are all considered in the development of Mughal imperial civility. This man's career and oeuvre speak holistically to a literary ecosystem at its height, self-consciously signaling its centrality to every corner of the Persianate world, with his writings enlivening every chapter. Most of the book's pages contain Persian phrases; some offer a critical lexicon to specialized readers, while others seem unnecessary and slow down the reader. Nonetheless, Kinra's English translations are crisp and engaging.

Writing Self, Writing Empire is a valuable contribution to literary history and criticism. South Asianists will benefit from this revisionist account of Mughal historiography. Scholars of Persian should read the book as a model of literary criticism that keeps sight of the politics of canon formation and the complex process in which literary figures become enshrined or marginalized, often as an outgrowth of different nationalist paradigms. Cultural historians will find the author's appraisal of $t \bar{a} z a-g \bar{u} ' \bar{\imath}$ timely and relevant, particularly in light of revisionist studies on European Mannerism. Writing Self, Writing Empire is a welcome addition to a growing corpus of work by scholars like Mana Kia, Audrey Truschke, Arthur Dudney, and Kevin Schwartz that seeks to map the social space of Persian in pre-colonial South Asia. 